\title{
ЗМІСТ КОРЕКЦІЙНО-РОЗВИВАЛЬНОЇ РОБОТИ З МОЛОДШИМИ ШКОЛЯРАМИ З ОСОБЛИВИМИ ОСВІТНІМИ ПОТРЕБАМИ
}

Анотація. Статтю присвячено розкриттю змісту корекційно-розвивальної роботи з молодшими школярами з особливими освітніми потребами. Наведено категорії дітей з особливими освітніми потребами (діти з вадами слуху; діти з порушеннями зору; діти з порушеннями мовлення; діти з порушеннями інтелекту; діти з порушеннями опорно-рухового апарату; діти з порушеннями емоційно-вольової сфери; діти з затримкою психічного розвитку; діти зі складними недоліками розвитку; діти з тяжкими порушеннями мовлення; діти з проблемами соціального змісту; діти з цифровою залежністю). Розкрито поняття «корекційно-розвивальна робота». Визначено основні умови ефективності корекційно-розвивальної роботи 3 учнями початкової школи з особливими освітніми потребами, що впливають на їх психологічний розвиток. Окреслено основні напрямки корекційно-розвивальної роботи з молодшими школярами та завдання, які мають бути вирішені під час корекційно-розвивальної роботи з дітьми з особливими освітніми потребами. Ключові слова: завдання, зміст, категорії дітей, корекційно-розвивальна робота, молодші школярі, напрямок, особливі освітні потреби, умови.

Miroshnyk Iryna, Sidun Alona T.H. Shevchenko National University "Chernihiv Colehium"

\section{THE CONTENT OF THE CORRECTIONAL AND DEVELOPMENTAL WORK WITH PRIMARY SCHOOLCHILDREN WITH SPECIAL EDUCATIONAL NEEDS}

Summary. The article is devoted to the content of the correctional and developmental work with primary schoolchildren with special educational needs. The categories of children with special educational needs (the children with hearing disorders; the children with visual disorders; the children with speech disorders; the children with intellectual disorders; the children with musculoskeletal disorders; the children with emotional and volitional disorders; the children with mental disorders; the children with severe developmental disorders; the children with severe speech disorders; the children with social problems; the children with digital dependence) have been given. The concept of the "correctional and developmental work" has been revealed. The main conditions for the effectiveness of the correctional and developmental work with primary school children with special educational needs, which affect their psychological development, have been determined. The main directions (the development of visual / auditory perception, speech, attention, memory, imagination, cognitive activity; the psychophysiological and social-communicative development of children with special educational needs; the development of children's emotional, speech, subject-action and play communication with the environment; spatial, temporal and social orientation, etc. skills formation; the development of children's self-development and self-regulation skills through the communication with the environment, taking into account knowledge, skills and abilities of communication and creativity; creating the conditions for social rehabilitation and integration of children with special educational needs; the development of children's independence and vital competencies) and the objectives (to form social skills and abilities for further successful socialization of the child; to deepen the idea and consolidate the knowledge about the world around: to know and distinguish the seasons, months of the year, days of the week, weather phenomena; to form an understanding and sense of time: to have an idea of age changes (date of birth, 1 year older, transition to the next form); to develop the ability to navigate in time (using the calendar, determining the date), to correlate the events of personal life with real time (yesterday, today, tomorrow)), which must be achieved during the correctional and developmental work with children with special needs, have been outlined.

Keywords: objectives, content, categories of children, correctional and developmental work, primary schoolchildren, direction, special educational needs, conditions.

Постановка проблеми. Соціальні зміни, 1 які відбуваються протягом останнього десятиліття є досить важливими та зумовлені гуманізацією свідомості суспільства. Тому в соціумі є повноцінне розуміння того, що люди з особливими потребами потребують допомоги та підтримки, як від держави, так і від суспільства, а також повноцінної інтеграції у соціум.

В історії світової науки проблема дітей з порушенням здоров'я викликає міждисциплінарний науковий інтерес і розглядається як специфічний розвиток, зумовлений в першу чергу соціальними, медичними, психологічними й педагогічними чинниками. Як самостійне явище і об'єкт наукового дослідження, ця проблема торкається питань економіки, політики, права, соціології, медицини, психології та педагогіки.

Кількість дітей, які мають потребу у корекційному навчанні постійно зростає, зумовлюючи актуальність проблеми інклюзивної освіти (IO). Відповідно одним із пріоритетних напрямків політики України на сьогодні є організація та вдосконалення інклюзивного освітнього середовища. Як і більшість країн світу, наша країна спрямувала концепцію IO на роботу з людьми, зокрема з дітьми, з особливими потребами.

Аналіз останніх досліджень та публікацій. Здійснивши аналіз останніх досліджень та публікащій, доходимо висновку, що є пращі, в яких розкрито основи IO $[4 ; 5]$; проаналізовано соціокуль- 
турний фон освітніх змін для людей з особливими потребами в Україні [7, с. 87-96]; окреслено стратегії демонстрації навчальних матеріалів у закладах IO [2]; обгрунтовано едективність використання IO в інклюзивній освіти [1] тощо.

Виділення не вирішених раніше частин загальної проблеми. До проблеми навчання дітей 3 особливими освітніми потребами (ООП) у своїх працях звертається багато зарубіжних та вітчизняних вчених (В. Андрущенко, В. Сухомлинський, М. Ярмаченко, С. Андрєева, В. Бондарь, Т. Ілляшенко, А. Колупаєва, Н. Сабат, С. Ярська-Смирнова, О. Акімова, Т. Лорман, Ш. Крокер, Дж. Депплер та ін.). Хоча проблемі навчання дітей з ООП і приділяеться значна увага вчених, проте саме зміст корекційно-розвивальної роботи (КРР) з молодшими школярами з ООП потребуе уточнення, оскільки така робота має свою специфіку, зміст та завдання.

Мета статті - розкрити зміст КРP з учнями початкової школи з ООП; визначити основні напрями КРР з молодшими школярами з ООП.

Виклад основного матеріалу.

Розрізняють такі категорії дітей з ООП:

1) діти з вадами слуху;

2) діти з порушеннями зору;

3) діти з порушеннями мовлення;

4) діти з порушеннями інтелекту;

5) діти з порушеннями опорно-рухового апарату;

6) діти з порушеннями емоційно-вольової сфери;

7) діти з затримкою психічного розвитку;

8) діти зі складними недоліками розвитку;

9) діти з тяжкими порушеннями мовлення;

10) діти $з$ проблемами соціального змісту;

11) діти з цифрровою залежністю.

Тому виховна, КРР дітей з ООП повинна бути комплексною, охоплювати всі аспекти їх особистісного розвитку. Навчання має бути практичним, оскільки, 3 одного боку, доступні для дитини види діяльності (теми, ігри, спілкування, праця тощо) стануть джерелом знань про навколишне середовище, за допомогою якого світ можна зрозуміти і змінити, з іншого - сприятимуть використанню та закріпленню знань та навичок, а власний досвід сформує в них здатність адаптуватися до соціального середовища.

Обов'язковим у КРР є те, що допомога, яка має надаватися кожній дитині, носить індивідуальний характер, має різну спрямованість і повинна тривати протягом всього їі життя.

Корекиійно-розвивальна робота - це система діяльності, що дозволяе виконувати завдання щодо своєчасного надання допомоги дітям з ООП, які навчаються в загальноосвітніх навчальних закладах.

Зміст КРР визначається відповідно до особливостей, цілей і напрямів розвитку дітей із ООП [3].

Відповідно до Закону України «Про освіту», сьогодні кожна дитина з відхиленнями має право на отримання відповідної для її психофрізичного розвитку освіти. Велика кількість досліджень у галузі спеціальної педагогіки та психології підтвердила, що правильно організована система навчання та виховання ціеї групи дітей позитивно впливає і призвела до значного прогресу в адаптації до соціального життя.

Основнили напрялками КРР 3 дітьми з ООП є:

- розвиток зорового / слухового сприймання, мовлення, уваги, пам'яті, уяви, пізнавальної діяльності;
- психофізіологічний та соціально-комунікативний розвиток дітей з ООП;

- розвиток емоційного, мовленневого, предметно-дійового та ігрового спілкування дітей з навколишнім середовищем;

- формування навичок просторової, часової та соціально-побутової орієнтації тощо;

- розвиток навичок саморозвитку та саморегуляції дітей за допомогою зв'язку з навколишнім середовищем, враховуючи знання, уміння і навички комунікативної діяльності і творчості;

- створення умов для соціальної реабілітації та інтеграції дітей з ООП;

- розвиток їх самостійності та життево необхідних компетентностей.

Аналізуючи літературу та практичний досвід психологів і вчених, ми дійшли до висновку, що своєчасне проведення комплексної корекційної роботи вплине на позитивні зміни в когнітивній та емоційно-вольовій сферах. Діти з незначними порушеннями можуть досягти розвитку та подолати труднощі в оволодінні знаннями, навичками та вміннями, якщо вони якомога швидше інтегруються в системну КРP, що безпосередньо вплине на успішність їх реабілітації та соціальної адаптації. Така робота має бути спрямована лише на індивідуальну диференціацію, включно $з$ усіма напрямами психофізіологічного розвитку дітей, з урахуванням тяжкості вад, стану здоров'я та індивідуальних особливостей нервової системи.

КРР має відігравати ключову роль у вихованні та навчанні дітей з порушеннями психофізичного розвитку у загальноосвітніх навчальних закладах. Крім того, КРР є невід'ємною частиною загальної освіти, і водночас має свою специфрічну спрямованість відповідно до захворювання дитини.

У свою чергу, основу спеціальних методів та прийомів КРР складають загально-педагогічні підходи, спрямовані на розвиток, збереження чи відновлення порушених фрункцій організму, знань та умінь дитини. До них належать методи переконань, прикладів, стимулювання покращення поведінки і діяльності дітей, що мають порушення.

КРР реалізується у спеціально організованих корекційно-розвивальних класах, а їі суть чітко прописана в Державному стандарті загальної освіти початкової школи для дітей з ООП. Передбачено такі корекційно-розвиваючі заняття для дітей з вадами інтелекту: «Лікувальна фрізкультура», "Ритміка», «Психосоціальний розвиток», «Розвиток мовлення». Кожен із визначених напрямів конкретизуеться у змісті корекційних програм, що вперше були розроблені в Україні на основі передового досвіду спеціальних навчально-виховних закладів.

У процесі організації КРР для дітей з ООП необхідно враховувати компенсаторну здатність організму, тобто позитивні зміни у розвитку дітей під впливом цілеспрямованого та організованого навчання. Саме тому такий вид педагогічної роботи $є$ основною та неодмінною умовою успішної участі дітей в інклюзивній освіті.

У навчальному процесі для корекції та розвитку використовуються різноманітні методи та організаційні форми роботи. Такий навчальний процес, основною метою якого є корекція розви- 
тку дітей, називається корекційно спрямованим і передбачає корекційне навчання та корекційне виховання.

Під час КРP з учнями початкової школи з ООП мають бути вирішені такі завдання:

- сорормувати соціальні вміння та навички для подальшої успішної соціалізації дитини, наприклад: не боятись запитати щось, вислухати співбесідника, дати відповідь на запитання, дочекатися своєї черги, не перебивати один одного, співчувати, співпереживати, тримати в пам'яті інформацію про іншу людину тощо;

- поглибити уявлення та закріпити знання про навколишній світ: знати і розрізняти пори року, місяці року, дні тижня, явища погоди;

- сорормувати розуміння та відчуття часу: мати уявлення про вікові зміни (дата народження, на 1 рік старший, перехід в наступний клас);

- розвивати вміння орієнтуватися в часі (використання календаря, визначення дати), співвідносити події особистого життя з реальним часом (вчора, сьогодні, завтра).

Отже, ефрективність результатів КРP з учнями початкової школи з ООП буде досягнута завдяки створенню комфортних умов для навчання дітей з ООП; коректному добору та організації позакласних заходів для змоги долучення дітей з ООП до участі в них, а також прояву своїх здібностей; використанню таких видів, форм і методів роботи, щоб учні з ООП могли розвивати своє мовлення та інші психічні якості; проведенню корекційної роботи, яка націлена на емоційно-вольову сфреру та поведінку дітей; розвитку у дітей уявлення про навколишне середовище; збагаченню словникового запасу та розвитку уміння будувати речення та розповідь; корекції індивідуальних прогалини в знаннях молодших школярів.

Особливо важливим для КРP дітей з ООП є зацікавленість батьків у вирішенні проблеми. Вони повинні бути активними учасниками навчально-виховного процесу, що готові допомогти своїм дітям у будь-який час. Хто вірить у своїх дітей, той вірить, що інклюзивна освіта та корекційна робота ефективні та принесуть позитивні результати [6].

Висновки і пропозиції. Таким чином, у навчанні дітей з ООП особливого значення набуває зміст КРР, що передбачає вирішення низки завдань, пов'язаних з забезпеченням едективності їх корекційного розвитку. Тому одним із пріоритетних напрямків освітньої політики в Україні на сьогодні є організація та вдосконалення змісту та умов інклюзивного освітнього середовища. Для цього потрібно організувати таке інклюзивне середовище в закладах освіти, у тому числі і початковій школі, щоб кожна дитина відчувала значимість свого існування, вірила у свої можливості і бачила результати своєї роботи.

\section{Список літератури:}

1. Гевко І.В. Значення інноваційних технологій при здійсненні інклюзивної освіти. Педагогічний альманах : збірник Комунального вищого навчального закладу "Херсонська акаделія неперервної освіти" Херсонської обласної ради. 2018. Вип. 37. С. 236-240.

2. Данілавічюте Е.А. Стратегії викладання в інклюзивному навчальному закладі : навч.-метод. посіб. Київ : Видавнича група «А.С.К.», 2012. 287 с.

3. Державний стандарт початкової загальної освіти для дітей з особливими освітніми потребами. МОН України, НАПН України, Інститут спеціальної педагогіки. Київ, 2013. URL: http://mon.gov.ua/activity/education/ zagalna-serednya/osvita-osib-z-osoblivimi-potrebami/normativno-pravova-baza.html

4. Колупаєва А.А., Таранченко О.М., Білозерська I.О. та ін. Основи інклюзивної освіти : навч.-метод. посіб. / за заг. ред. А.А. Колупаєвої. Київ : А.С.К., 2012. 308 с.

5. Порошенко М.А. Інклюзивна освіта : навч. посібник. Київ : ТОВ «Агентство «Україна», 2019. 300 с.

6. Седнева В.О. Основи корекційної роботи з учнями, які мають особливості психофрізичного розвитку : методичні рекомендації. Миколаїв : ОІППО, 2011. 36 с.

7. Таранченко О.М. Соціокультурний контекст змін в освіті осіб з особливими потребами в Україні. Особлива дитина: навчання $і$ виховання. 2016. № 4(80). С. 87-96.

\section{References:}

1. Hevko I.V. (2018) Znachennia innovatsiinykh tekhnolohii pry zdiisnenni inkliuzyvnoi osvity [The importance of innovative technologies in the implementation of inclusive education]. Pedahohichnyi almanakh: zbirnyk Komunalnoho vyshchoho navchalnoho zakladu Khersonska akademiia neperervnoi osvity Khersonskoi oblasnoi rady [Pedagogical Almanac: Collection of the Communal Higher Educational Institution "Kherson Academy of Continuing Education" of the Kherson Regional Council], vol. 37, pp. 236-240.

2. Danilavichiutie E.A. (2012) Stratehii vykladannia v inkliuzyvnomu navchalnomu zakladi [Teaching strategies in an inclusive educational institution]. Kyiv: «A.S.K.». (in Ukrainian)

3. Derzhavnyi standart pochatkovoi zahalnoi osvity dlia ditei z osoblyvymy osvitnimy potrebamy [State standard of primary general education for children with special educational needs] (2013) MON Ukrainy, NAPN Ukrainy, Instytut spetsialnoi pedahohiky. Available at: http://mon.gov.ua/activity/education/zagalna-serednya/osvita-osibz-osoblivimi-potrebami/normativno-pravova-baza.html

4. Kolupaieva A.A., Taranchenko O.M., Bilozerska I.O. and others (2012) Osnovy inkliuzyvnoi osvity [Bases of inclusive education]. Kyiv: A.S.K. (in Ukrainian)

5. Poroshenko M.A. (2019) Inkliuzyuna osvita [Inclusive education]. Kyiv: «Ahentstvo «Ukraina». (in Ukrainian)

6. Siednieva V.O. (2011) Osnovy korektsiinoi roboty z uchniamy, yaki maiut osoblyvosti psykhofizychnoho rozvytku [Bases of correctional work with the pupils who have features of psychophysical development]. Mykolaiv: OIPPO. (in Ukrainian)

7. Taranchenko O.M. (2016) Sotsiokulturnyi kontekst zmin v osviti osib z osoblyvymy potrebamy v Ukraini [Sociocultural context of changes in the education of people with special needs in Ukraine]. Osoblyva dytyna: navchannia $i$ vykhovannia [Special child: education and upbringing], no. 4(80), pp. 87-96. 